\title{
TRIPLEX SENTENTIA CONFORMIS W PRAWIE DEKRETAŁÓW
}

Zakaz trzeciej apelacji przejęty przez Gracjana z prawa rzymskiego do kanonistyki 1, został szerzej opracowany przez dekretystów, którzy uczynili z niego zasadę ogólną kościelnego prawa procesowego, wyłączając spod tej zasady sprawy małżeńskie i inne sprawy duchowe (causae spirituales) i uzasadniając to wyjęcie względami etycznymi ${ }^{2}$.

Nauka dekretystów w tej sprawie nie posiadała wprawdzie potwierdzenia w ustawodawstwie kościelnym, ale stanowiła doskonały podkład teoretyczny do takiego potwierdzenia, które doszło do skutku pod koniec XII wieku mocą dekretałów papieskich.

Rolę łącznika między nauką dekretystów a oficjalnym ustawodawstwem kościelnym normującym sprawę ilości dozwolonych apelacji spełnia twórca pierwszej kompilacji i jeden $\mathrm{z}$ pierwszych dekretalistów Bernard $\quad z \quad P$ awi i 3 .

Jego stanowisko w tej sprawie nie jest jasne. Po wyroku i w stosunku do tego samego capitulum dopuszcza on tylko dwie apelacje, natomiast przed wyrokiem, jego zdaniem, można apelować tyle razy, ilekroć znajdzie się wyższego sędziego. Możliwość apelacji przed wyrokiem ilustruje on wyliczeniem całej hierarchii sędziów kościelnych, począwszy od archidiakona aż po papieża ${ }^{4}$. Wprawdzie wszyscy wymienieni przez Bernarda

1 Zob. Pieronek T., Zakaz trzeciej apelacji w Dekrecie Gracjana, Analecta Cracoviensia 7 (1975) 403-410.

2 Pieronek T., Zakaz trzeciej apelacji i niezmienność wyroku w sprawach matżeńskich u dekretystów, Prawo Kanoniczne 20 (1975) $\mathrm{nr} 1-2,259-266$.

3 Bernard z Pawii, profesor w Bolonii, późniejszy biskup w diecezji Faenza, twórca pierwszej Summa decretalium, napisanej w latach 1191-1198. Zob. Bernardi Papiensis Summa decretalium, wyd. E. Laspeyres, Ratisbonae 1860, s. LXI; Van Hove A., Prolegomena ad Codicem Iuris Canonici, Mechliniae 1945, wyd. 2, s. 447.

${ }_{4}^{4}$, ,Nunc videndum est, quotiens possit appellari; et quidem post sententiam bis tantum super eodem capitulo, ut C. II, qu. 6 \& Post secundam (Grat. ad c. 39), ante sententiam quotiens superior iudex invenitur, nimirum ab archidiacono vel archi- 
z Pawii hierarchowie posiadali w XII wieku władzę sądową ${ }^{5}$, niemniej wydaje się, że to co mówi on o apelacji przed wyrokiem, należy rozumieć o rekursie pozasądowym, a nie o apelacji w sensie ścisłym ${ }^{6}$.

Wyrazem nauki dekretystów i pierwszego z dekretalistów Bernarda z Pawii były dekretały papieskie, oficjalnie rozstrzygające wątpliwości prawne dotyczące liczby dopuszczalnych apelacji w procesie kanonicznym.

Pierwszym takim rozstrzygnięciem był dekretał Directae ${ }^{7}$ pap. Klemersa III (1187-1191). Stwierdza on, że jeżeli strona procesowa apeluje, ale nie poprze swej apelacji i wróci do sędziego a quo i zostanie przez niego obciążona, mimo porzucenia pierwszej apelacji, ma prawo do drugiej ${ }^{8}$.

Jakkolwiek dekretał ten przede wszystkim zezwalał na drugą apelację, to jednak wyraźnie został zrozumiany także jako zakaz dalszych apelacji i doprowadził do utrwalenia w kanonistyce jednolitej opinii na ten temat.

Jednym z pierwszych wyrazicieli tej opinii był Tankred z Bolonii w swoim Ordo iudiciarius 9. Powtarzając niejako myśl Magistra Rufina, stawiał on już zupełnie jasno zasadę, że zarówno przed wyrokiem definitywnym, jak i po nim, w tej samej sprawie i w stosunku do tego samego capitulum, wolno apelować tylko dwa razy. Był on równocześnie świadom, że niektóre kanony nie wypowiadały się na ten temat zdecydowanie i dlatego wyjaśniał: ponieważ ta sama sprawa często zawiera kilka capitula, w stosunku do każdego z nich dozwolone są dwie apelacje, co w sumie pozwala na wielokrotną apelację przed wyrokiem. Po wyroku wolno apelować dwukrotnie. Wyrażenie "quotiens opus est, appellari potest”

presbytero gravatus recte ad episcopum appellabit, et ab episcopo super eodem capitulo gravatus recte ad archiepiscopum, itemque ab ipso gravatus ad patriarcham, demum super eodem a patriarcha gravatus ad dominum papam appellabit, ut C. II. qu. 6 Omnis (c. 3) et Di. XCIX. Provinciae (c. 1), et C. III. qu. 6 Pulsatus (c. 3)": Bernardi Papiensis Summa decretalium, lib. 2, tit. 2Q, $\S 5$ (wyd. E. Laspeyres, S. $60-61)$.

5 Amanieu A., Archipretre, W: Dictionnaire de Droit Canonique, t. I, kol. 1014: Amanieu A., Archidiacre, W: Dictionnaire de Droit Canonique, t. I, kol. 965-969.

${ }_{6} \mathrm{Na}$ takie rozumienie tekstu Bernarda z Pawii naprowadza zestawienie go z glosą Jana Teutonika do C. 2, q. 6, c. 1. Glosa ta stwierdza, że zasada ,secundum canones appellatur quotiens superior iudex invenitur", odnosi się do apelacji ,ante litem contestatam", a więc do rekursu pozasądowego. Bernard z Pawii stosuje tę zasadę do apelacji ,,ante sententiam". W tego typu apelacjach mieści się zarówno rekurs pozasądowy, jak i apelacja sądowa od wyroków przedstanowczych. Określenie ,ante sententiam” jest więc w tym wypadku nieścisłe i może budzić wątpliwości, czy zdaniem Bernarda z Pawii była dopuszczalna wielokrotna apelacja od wyroków przedstanowczych.

$7 \mathrm{X}, 2,28,39$. Bliższa data tego dekretału nie została ustalona. Zob. Regesta Pontificum Romanorum, wyd. Ph. Jaffé, t. II Ab a. 1143 ad a. 1198, Lipsiae 1888, s. 576, n. 16640 .

8 Dekretał Directae został zaopatrzony przez Mikołaja de Tudeschis w następującą rubrykę: „Si appellans, qui non prosequitur, redit ad iudicem a quo, et iterum gravatur, non obstante prima desertione potest iterum appellare".

9 Dzieło to zostało zredagowane w latach 1214-1216. Zob. Schulte F., Die Geschichte der Quellen und Litteratur des canonischen Rechts, t. I, Graz 1956, 204; Van Hove A., Prolegomena, 452. 
należy tak rozumieć, że wolno apelować ilekroć to jest potrzebne, nigdy jednak ponad dwa razy ${ }^{10}$.

Nieco później, za pontyfikatu pap. Honoriusza III (1216-1227) miało miejsce następne rozstrzygnięcie Stolicy Apostolskiej dotyczące tego samego problemu.

W procesie o pewną sumę pieniężną sędzia zwyczajny wydał wyrok na korzyść powoda. Ten wyrok na skutek dwukrotnej apelacji pozwanego został potwierdzony przez dwa następne wyroki trybunałów delegowanych przez Stolicę Apostolską. Pozwany apelował po raz trzeci, ale apelacja ta została przez sędziego odrzucona wyrokiem przedstanowczym (,,interlocutus”), a stanowisko sędziego zostało potwierdzone przez papieża jako słuszne w dekretale Sua nobis ${ }^{11}$.

O ile c. Directae zezwalało na drugą apelację, o tyle c. Sua nobis zabrariało trzeciej. Obydwa dekretały odnosiły się do wyroków definitywnych, ale w nauce prawa panował już wówczas pogląd, że zakazem tym objęty jest każdy wyrok $\mathrm{w}$ tej samej sprawie i. w stosunku do tego samego capitulum ${ }^{12}$.

Nie przeszkadzało to jednak znanemu kanoniście Henrykowi de Segusia († 1271) wyłączać spod tego zakazu sprawy małżeńskie ze względu na charakter tych spraw ${ }^{13}$.

10 ,Quotiens appellari potest? Respondeo, ante sententiam super quolibet articulo bis potest appellari, nisi ob causam aliquam inferius numerandam appellatio inhibeatur... Unde, cum plura capitula sint saepe in una causa et super quolibet bis possit appellari, sequitur, quod quinquies vel etiam pluries in una causa possit appellari. Quod de plano concedo in appellationibus, quae fiunt ante sententiam. Post sententiam vero difinitivam bis tantum appellare licet; nimis nempe durum esset quartam exspectare sententiam... Et licet quidam canon videatur innuere, quod ultra duas vices possit appellari, - ait enim quotiens opus est, appellari potest, ut C. 2. q. 6. c. omnis oppressus, 3. et c. quotiens 16. -; tenendum est, quod supra diximus, et intelligitur illud, quod possit appellari quotiens opus est, ante diffinitivam sententiam, vel etiam post sententiam appelletur quotiens opus est, non tamen ultra secundam vicem": Tancredi Bononiensis, Ordo iudiciarius, p. 4, tit. 5 de appellationibus, § 9. Pillii, Tancredi, Gratiae libri de iudiciorum ordine, wyd. F. Bergmann, Gottingae 1842, s. 296-297. Jeszcze Ryszard Anglicus, w Summa de ordine iudiciario pisanej w 1196 r. (Van Hove A., Prolegomena, 452), zajmuje w tej kwestii stanowisko bliskie dekretystom. Zob. Die Summa de ordine iudiciario des Ricardus Anglicus, Quellen zur Geschichte des Römisch-Kanonischen Processes im Mittelalter, wyd. L. Wahrmund, cz. II, zesz. 3, Innsbruck 1915, 85.

$11 \mathrm{X}, 2,28,65$. Bliższa data tego dekretału nie jest ustalona. Zob. Regesta Pontificum Romanorum, wyd. A. Potthast, t. I Ab a. 1198 ad. a. 1304, Berolini 1874, 669 , n. 7775.

12 Quoties appellandum sit clarum est, quoniam regulariter super quolibet articulo vel gravamine et qualibet interlocutoria ante sententiam et etiam a sententia diffinitiva, bis tantum appellatur et non tertio... Unde cum multa sint capitula in causa ante litis contestationem, multoties potest appellari, ut dixi, post sententiam etiam tantum bis. Et secundum hoc intelligi 2, q. 6 omnis oppressus et c. ad Romanam et c. quoties et c. ideo": Durandus Gulielmus, Speculum iuris, Francoforti 1592, 2, de appellationibus, 3, § 8; Gottofredo da Trani, Summa super titulos decretalium, Aalen 1968 (Neudruck der Ausgabe Lyon 1519), lib. 2, de appellationibus, n. 13 (wyd. Aalen 1968, 242-243).

13 W swojej Summa aurea napisanej m. r. 1250 a 1261 (Zob. Schulte F., Die Geschichte, t. II, 126) pisze on: „dic quod potuit ibi tertio appellare, etiam ab eadem 
Celem tego zakazu była zdaniem Tankreda zbytnia uciążliwość, jaką powodowałoby czekanie na czwarty wyrok ${ }^{14}$, zaś według glosy c. Omnes episcopi ${ }^{15}$ do $v$. quotiens, by spory nie przeciągały się $\mathrm{w}$ nieskończoność ${ }^{16}$. Ponadto glosa do c. Si autem ${ }^{17}$ do v. Tertio in eadem wskazuje na domniemanie sprawiedliwego rozstrzygnięcia sporu, jakie powstaje w następstwie wydania trzech wyroków, z których drugi i trzeci potwierdzają pierwszy ${ }^{18}$.

W samej rzeczy w praktyce sądowej spór nie zawsze kończył się trzecim wyrokiem, bo prawo do dwóch apelacji przysługiwało obydwu procesującym się stronom, a ponadto istniało szereg innych możliwości uniknięcia skutków niekorzystnego wyroku.

Najbardziej plastyczny obraz mogącego powstać w ten sposób długotrwałego sporu notuje Wilhelm Durand w swoim Speculum iuris, wskazując na możliwość czterech apelacji w tej samej sprawie i w stosunku do tego samego capitulum. Możliwość taka istniała wówczas, gdy trybunały orzekające w procesie przyznawały słuszność na przemian (,,interpellatim"), to jednej, to drugiej stronie procesowej ${ }^{19}$. Tego typu apelacja

sententia, propter qualitatem causae matrimonialis de qua ibi loquitur a qua et ter et quater ea quoties visum fuerit appellari potest in rem non transeat iudicatam": Henricus de Segusia, Summa aurea, Venetiis 1570, lib. 2, de appellationibus, tit. quoties.

${ }_{14}, \ldots$ nimis nempe durum esset quartam exspectare sententiam": Tancredi Bononiensis, Ordo iudiciarius, p. 4, tit. 5, de appelationibus, $\S 9$, wyd. F. Bergmann, 296.

15 C. 2 , q. 6 , c. 5 .

16 ,ne lites in infinitum extendantur".

17 C. 2 , q. 6 , g. 39 .

18 ,Ergo qui bis appellavit non auditur tertio appellans, hoc ideo quia presumitur quod totiens iuste condemnatus sit et non gravetur".

19 ,quod autem dixi bis posse appellari tantum a sententia vel a quolibet gravamine, intellige verum ab eadem parte. Nam altera pars poterit etiam super eodem capitulo vel sententia appellare. Si enim appellavero a sententia pro te contra me lata et iudex appellationis sententiam confirmat, possum secundo appellare a confirmatione sententiae. Sed si haec confirmatio confirmetur, non possum amplius appellare, quia non licet tertio provocare. Si autem confirmatio infirmetur, tu poteris ab illa sententia appellare, quia hoc non est tertia appellatio, sed prima quo ad te. Et si iudex appellationis infirmationem sententiae infirmet, poteris secundo appellare, ultra tibi non licet et sic sunt praedicta iura intelligenda. Et secundum hoc super quolibet articulo potest quarto appellari. Et sic obtinuit, licet audiverim quendam contrarium sustinentem, ut tantum bis appellatur, sicut iuris verba tenent. Idem etiam credo, si interpellatim fiant appellationes, ut si a sententia lata pro te contra me ego appello et in causa appellationis obtineo, demum tu secundo appellas et obtines, tertio ego appello et obtineo. Et quarto tu appellas et obtines. Certe nulli nostrum licet ulterius appellare, quia nulli nostrum licet tertio appellare et sufficit sic scriptum esse": Durandus G., Speculum iuris, 2 de appellationibus, 3 , § 8. Powyższy tekst przytaczam w całości z tego względu, że dał on w kanonistyce powód do różnych rozważań teoretycznych na temat pozycji prawnej powoda i pozwanego, posługujących się apelacją przemienną. Tekst ten powtórzy w swoich komentarzach szereg poważnych dekretalistów, nie zauważając w nim błędu, który wytknie autorowi Speculum iuris dopiero w XVII wieku prawnik z Neapolu Scaccia S., Tractatus de appellationibus in duas partes et viginti quaestiones divisus, Romae 1612 , lit. 3 , cap. 2 , q. 17 , limit. 1 , n. 58 . 
przemienna była więc możliwa tak długo, aż obydwie strony wykorzystały przysługujące im prawo do dwóch apelacji.

Nie wszyscy autorowie jednak zgadzali się $z$ taką interpretacją uprawnień stron do apelacji i dopuszczali w sporze tylko dwie apelacje, niezależnie od tego, która ze stron je złożyła.

Opinia opowiadająca się za ścisłą interpretacją zakazu trzeciej apelacji nie była jak się wydaje rozpowszechniona i w praktyce była stosowana tylko w niektórych trybunałach lokalnych ${ }^{20}$.

Możliwość długotrwałego sporu wynikała nie tylko z dopuszczenia czterech przemiennych apelacji w tej samej sprawie. Owczesna praktyka sądowa, na którą wskazuje również Durand, pozwalała na dalsze kombinacje, polegające na łączeniu z apelacją skargi o nieważność wyroku.

Praktyka taka umożliwiała wielokrotne zwalczanie wyroku, mimo wyczerpania dopuszczalnych apelacji i doprowadzała do sytuacji, w której zakaz trzeciej apelacji stawał się fikcją, a w każdym razie nie spełniał swej roli w wymiarze sprawiedliwości. Poszkodowany wyrokiem mógł bowiem przy zgłoszeniu i poparciu apelacji, zaskarżyć jego ważność. Niezależnie od tego, czy tak zaskarżony wyrok został uznany za ważny czy nieważny, można było na nowo apelować i zwalczać ważność któregokolwiek z niezaatakowanych jeszcze wyroków i w ten sposób postępując, prowadzić spór w nieskończoność ${ }^{21}$.

Powody takiego stanu rzeczy były zapewne różnorodne. Pieniactwo, żądza zemsty i inne słabości ludzkie grały tu niewątpliwie swoją rolę. Ale i prawo procesowe, jak się wydaje, nie było bez winy. Nie domagały przepisy dotyczące egzekucji wyroku, rozpowszechniona była praktyka sądów delegowanych różnego stopnia, co ułatwiało apelację, nieuporządkowane i dalekie od doskonałości były normy regulujące zagadnienie nieważności i zaskarżalności wyroku ${ }^{22}$.

20 Durandus G., Speculum iuris, 2, de appellationibus, 3, § 8, przypisuje taka ścisłą interpretację zakazu trzeciej apelacji Hubertowi z Bobio: „Ubertus dicit quod non licet tertio appellare; verum est continue... sed interpellatim bene licet". O lokalnej praktyce takiej interpretacji mówi jeszcze w pierwszej połowie XVI wieku Filip Decius: ,... quatuor appellationes super eodem articulo fieri possunt... Et secundum praedicta interpretari debet statutum quod disponit nisi semel posse appellari. Nam intelligitur ab eadem parte. Cum tamen hoc allegarem Senis, non potui obtinere quia practica erronea ibi inolevit, quod tantum semel praecisae appelletur": Decius Ph., In decretales commentaria, Romae 1579, X, 2, 65, n. 17-19.

Decius nazywa tę interpretację błędną. Wprawdzie wypadek przez niego przytoczony miał miejsce w Sienie i dotyczył prawa statutowego, to jednak prawo to należało interpretować zgodnie z prawem kanonicznym.

21 Durandus G., Speculum iuris, 2, de appellationibus, 3, § 8 przypisując autorstwo tego rozwiąania $\mathrm{Hubertowi} \mathrm{z}$ B obio, pisze: ,Item non licet tertio appellare, verum est in eodem capitulo, sed in diversis sic, etiam centies. Et docet (sc. Ubertus de Bobio) talem cautelam ut appellans appellando et prosequendo dicat primam sententiam nullam et si iudex appellationis dixerit eam aliquam vel iustam vel non iustam, statim poterit appellare et centies per hanc viam".

${ }_{22}$ Zab. Ghidotti E., La nullità della sentenza giudiziale nei diritto canonico, Milano 1965, 44-71, gdzie omawiana jest problematyka nieważności wyroku w De- 
O bezradności ówczesnego prawa wobec zasad dotyczących wykonania wyroku może świadczyć dyskusja, zreferowana w Speculum iuris a powstała w odpowiedzi na pytanie, która ze stron procesowych znajduje się w lepszej pozycji prawnej, jeżeli obydwie mają za sobą dwa potwierdzające wyroki i żadna z nich nie może już korzystać z apelacji.

Autor Speculum iuris przytacza dwie odmienne opinie prawników na ten temat. Według jednej opinii w lepszej sytuacji jest pozwany (,originalis reus"), bo - jak mówi Durand — ,skłonniejsi jesteśmy do uwolnienia niż do potępienia", czyli za pozwanym przemawia domniemanie niewinności. Według drugiej opinii lepszą pozycję ma ta ze stron procesowych, powód lub pozwany, która pierwsza uzyskała wyrok na swoją korzyść, a to $\mathrm{z}$ tego względu, że za wyrokiem przemawia domniemanie prawdy. Obydwie opinie podbudowuje Durand argumentami z prawa rzymskiego, sam jednak nie zajmuje wobec nich jasnego stanowiska, zostawiając sprawę otwartą dla dalszej dyskusji ${ }^{23}$.

Niebawem jednak spór ten został częściowo rozstrzygnięty powagą soboru wienneńskiego w $1311 \mathrm{r}$. za pap. Klemensa V (1305-1314). W cap. Ut calumniis:24 został nie tylko potwierdzony zakaz trzeciej apelacji, ale ustalono również, że po wydaniu w tej samej sprawie trzech wyroków, nie wolno zaskarżać ważności żadnego $\mathrm{z}$ nich, zanim nie zostaną one w pełni wykonane. Nie może też przeszkodzić wykonaniu trzech wyroków niezałatwiona jeszcze apelacja od ewentualnego wyroku przedstanowczego.

Rozwiązanie to, aczkolwiek na pierwszy rzut oka proste i przecinające wszelkie dyskusje, pozostawiło jednak pewne wątpliwości, które od razu zostały wskazane przez kanonistów.

Tak więc Jan Andrze jow y ( $\dagger$ 1348) w swoich uzupełnieniach (,additiones") do Speculum iuris Duranda wypowiedział pogląd, że

krecie Gracjana i u dekretystów. Wyrok można było zaskarżyć z bardzo wielu przyczyn. Właściwie dopiero Kodeks Prawa Kanonicznego w kan. 1892 i 1894 uporządkował i to też niezbyt precyzyjnie, kwestie nieważności i zaskarżalności wyrokku w prawie kanonicznym.

${ }_{23}$,Sed secundum praemissa, tu habuisti pro te duas sententias confirmatorias et ego pro me alias duas; quaeritur quis erit potior, cum nulli nostrum licet ulterius appellare. Et videtur quod originalis reus, quia promptiores sumus ad absolvendum quam ad condemnandum... imo videtur quod is, qui prius sententiam obtinuit, sive sit reus, sive actor, quia pro sententia praesumitur... hoc disputationi duximus relinquendum": Durandus G., Speculum iuris, 2, de appellationibus, 3, § 8, n. $2-3$.

${ }_{24}$ Clem, 2, 11, 1: ,Ut calumniis litigantium occurratur, is, qui in beneficiali vel alia quavis causa tres contra se in petitorio vel possessorio sententias reportavit, ad agendum de nullitate ipsarum vel alicuius ex eis nullatenus admittatur donec huiusmodi sententiae plenarie fuerint exsecutioni mandatae. Similiter si ille, contra quem tres sententiae diffinitivae latae fuerint, $a b$ interlocutoria vel gravamine ante prolationem ipsarum vel earum alicuius se appellasse, et causam appellationis huiusmodi adhuc pendere proponat: sententiarum praedictarum exsecutionem tali praetextu nolumus impediri. Quae ad causas qualitercunque etiam per appellationem pendentes duximus extendenda". 
zgodnie z dekretałem Ut calumniis w lepszym położeniu jest powód, jeśli pierwszy wyrok został wydany na jego korzyść. „Dekretał ten domaga się - pisze Jan Andrzejowy - by w wypadku, gdy powód ma na swoja korzyść trzy wyroki, dokonano w całości egzekucji, bez względu na to, że przeciwnik chciał lub chciałby skarżyć o nieważność lub zgłasza zarzut nieważności tych wyroków lub któregokolwiek z nich ${ }^{25}$."

$\mathrm{Z}$ reszty komentarza wynika, że zakaz dalszej apelacji w tej samej sprawie miał miejsce po wydaniu w niej trzech wyroków tylko wówczas, gdy pierwszy wyrok przyznawał racje powodowi i został potwierdzony albo przez dwa bezpośrednio po sobie następujące wyroki, albo przez którykolwiek z następnych, aż do czwartego wyroku włącznie, chociażby wyroki te były skutkiem apelacji przemiennej ${ }^{26}$.

Zdaniem Jana Andrzejowego żądanie pełnego wykonania trzech wyroków wydanych na korzyść powoda ${ }^{27}$ jest sprawiedliwsze wówczas, gdy pozwany uzyskał na swoją korzyść tylko jeden wyrok, albo zgoła żadnego, czyli wówczas, gdy w procesie wydano pierwszy wyrok na korzyść powoda i potwierdzono go dwoma bezpośrednio po sobie następującymi wyrokami ${ }^{28}$.

Praktyka sądowa wykazywała widocznie, że nie zawsze spory kończyły się tak jednoznacznie i dlatego autorzy rozważali także inne sytuacje, w których dochodziło do apelacji przemiennych ${ }^{29}$.

Przy okazji tych rozważań, zainicjowanych przez Duranda, warto zwrócić uwagę na stwierdzenia, które mogą być powodem nieporozumień.

Otóż w Speculum iuris, a później u Jana Andrzejowego i innych autorów, mówi się z jednej strony o tym, że istnieje możliwość apelacji przemiennej, a więc każdy spór dopuszcza teoretycznie cztery apelacje,

${ }_{25}$ Durandus G., Speculum iuris, 2, de appellationibus, 3, § 8, Additiones Joannis Andreae ad v. Relinquendum.

26 Tamże: „Actor enim, qui obtinuit primam (sc. sententiam) in principali, si habuit primam et secundam confirmatorias, statim debet hodie executionem petere. Idem si primam et tertiam. Si autem pro ipso est quarta et una de primis, nunc, et non prius, habet beneficium illius iuris" (sc. decr. Ut calumniis).

${ }^{27}$ Lektura Additiones Joannis Andreae do omawianego fragmentu Speculum iuris narzuca pytanie, dlaczego mówi on o lepszej pozycji powoda, a nie jednej ze stron procesowych. Wydaje się, że autor mówi w tym wypadku o powodzie przykładowo. Wskazuje na to użycie przez niego trybu warunkowego: "si habuit", „,si autem”. Jeżeli zatem pierwszy wyrok został wydany na korzyść pozwanego i potwierdzony przez następne, sytuacja ulega odwróceniu i pozycja prawna pozwanego staje się lepsza niż powoda.

28 , Fateor, quod maior est aequitas illius decretali quando reus nullam, vel unam solam pro se sententiam habuisset": Durandus G., Speculum iuris, 2, de appellationibus, 3, § 8, Additiones Joannis Andreae ad v. Relinquendum.

${ }_{29}$ Obok G. Duranda i Jana Andrzejowego (który mówi o tego rodzaju apelacji także $w$ swoich In secundum decretalium librum novella commentaria, Venetiis $1631, \mathrm{X}, 2,27,30$, n. 4), wspominaja o zagadnieniu m. in. Antonius a Butrio, In secundam secundi decretalium partem commentaria, Venetiis $1578, \mathrm{X}, 2,27,65$, n. 11; Nicolaus de Tudeschis, Commentaria tertiae partis in secundum librum decretalium, Venetiis $1588, \mathrm{X}, 2,27,65, \mathrm{n} .7$ oraz inni dekretaliści. 
których skutkiem jest pięć wyroków ${ }^{30}$ (trzy na korzyść 'jednej, a dwa na korzyść drugiej strony procesowej), a z drugiej strony rozważa się trudność, która ze stron procesowych posiada lepszą pozycję prawną, jeśli na korzyść każdej ze stron zostały wydane dwa potwierdzające wyroki, obydwie strony wykorzystały już prawo do dwóch apelacji i żadna $z$ nich nie może więcej apelować.

$\mathrm{Z}$ samego istnienia dyskusji na ten temat wynika, że uzyskanie trzech wyroków przez jedną ze stron procesowych nie powodowało automatycznie uprzywilejowanej pozycji prawnej tej strony, nie powodowało też tym bardziej przejścia wyroku w stan rzeczy osądzonej, na skutek wyczerpania liczby dopuszczalnych apelacji.

Dekretał Ut calumniis spowodował jedynie, że wbrew dotychczasowej praktyce, strona na której korzyść opiewały trzy zgodne wyroki miała natychmiastowe prawo do ich pełnego wykonania ${ }^{31}$, ale nie usankcjonował trzech zgodnych wyroków jako bezpośredniej przyczyny res iudicata.

Podstawą przejścia wyroku $\mathrm{w}$ stan rzeczy osądzonej był nadal tylko upływ dziesięciodniowego terminu po wydaniu wyroku, od którego nie złożono apelacji ${ }^{32}$.

Dużym postępem w dziedzinie skrócenia procesu był zakaz zawarty w dekr. Ut calumniis łączenia apelacji po trzecim zgodnym wyroku ze skargą o nieważność któregokolwiek z wyroków. Owszem, praktyka zaskarżania wyroku była dopuszczalna ${ }^{33}$, ale mogła mieć zastosowanie dopiero po wykonaniu wyroku ${ }^{34}$ i to wykonaniu całkowitym ${ }^{35}$, co oczywiście bardzo utrudniało działanie i zmuszało chętnych dalszego sporu do poważnej refleksji nad jego opłacalnością ${ }^{36}$.

${ }^{30}$ Durandus G. w Speculum iuris nie mówi wprawdzie wprost o pięciu wyrokach, ale posługuje się terminem ,sententia confirmatoria". Skoro obydwie strony procesowe apelowały dwukrotnie i każda $\mathrm{z}$ nich otrzymała na swoją korzyść dwa potwierdzające wyroki, to ogólna liczba wydanych wyroków musi wynosić pięć.

${ }^{31} \mathrm{O}$ innej praktyce przy egzekucji trzech wyroków przed dekr. Ut calumniis świadczy zdanie u Jana Andrzejowego, w którym stwierdza on, że ,nunc, et non prius", teraz, a nie przed dekretałem, skuteczne są trzy wyroki uzyskane nawet przy pomocy apelacji przemiennej. Kontekst cytatu z komentarza Jan a Andrzejo w e g o zob. wyżej nota n. 26

32 C. 2 , q. 6 , c. 28 .

33 „Secundo praesupponendum est quod licet ab una et eadem sententia non possim ter appellare, tamen possum illam dicere nullam et agere de nullitate; puta quia lata est die feriato vel me non citato, vel quod lata est iudice deambulante et non sedente pro tribunali... vel alleges aliquam aliam causam": Clem, 2, 11,1 , glosa ad v. Ut calumniis.

34 "Habens tres sententias conformes contra se, si agat de nullitate, antequam admittatur ad agendum, prius debet parere sententiae et executioni cum effectu": Notabilia ad Clem, 2, 11, 1.

35 ,Non facta executione etiam minime partis eius quod pronunciatum fuit impeditur agens": Clem, 2, 11, 1, glosa ad v. Plenarie.

36 Należy zwrócić uwagę, że w pierwszych latach XIV wieku Stolica Apostolska poczyniła jeszcze inne poważne kroki w celu skrócenia procesów w ogóle, a małżeńskich w szczególności. W 1306 r. pap. Klemens V ustalił w konstytucji Saepe con- 
$\mathrm{Na}$ tle tych nowych przepisów, które miały gwarantować szybszy i dosłonalszy wymiar sprawiedliwości w trybunałach kaścielnych, a także uwzględniając osiągnięcia ówczesnej kanonistyki w dziedzinie prawa procesowego, zachodzi pytanie, jaki wpływ miał dekretał Ut calumniis na rozstrzyganie spraw małżeńskich.

Okazuje się, że i do spraw małżeńskich, a nawet w ogóle do spraw duchowych dekretał miał pełne zastosowanie ${ }^{37}$. Nie było to przekreśleniem dorobku kanonistyki polegającego na opracowaniu zasady, że sprawy duchowe nie przechodzą nigdy w stan rzeczy osądzonej, a przeciwnie wprowadziło nowy element porządkujący sposób definitywnego załatwiania sporów także i w sprawach duchowych.

Odtąd, po trzech zgodnych wyrokach, we wszystkich rodzajach spraw należało je wykonać.

Obowiązek wykonania wyroku także i w sprawach duchowych, zwłaszcza małżeńskich, postawił na nowo problem niezmienności wyroku w tych sprawach. Wiadomo było, że sprawy małżeńskie nie przechodzą w stan rzeczy osądzonej, ale też trzy zgodne wyroki w tej samej sprawie kładły w jakiś sposób kres procesowi. Kanoniści musieli teraz dać odpowiedź na pytanie: pod jakimi warunkami, mimo trzech zgodnych wyroków i mimo ich wykonania, będzie można wznowić postępowanie w sprawach małżeńskich i jaki charakter ma posiadać to wznowienie.

Odpowiedzi na to pytanie udzielili dekretaliści z Innocentym IV (1243-1254) na czele, przy czym opracowali oni dokładniej w nauce prawa kanonicznego skutki zakazu trzeciejapelacji i trzech zgodnych wyroków.

W dzisiejszej kanonistyce panuje pogląd, że zasada o przejściu wyroku w stan rzeczy osądzonej na skutek wyczerpania wszystkich dopuszczalnych przez prawo stopni jurysdykcji sądowej, innymi słowy o tym, że res iudicata powstaje na skutek potrójnego zgodnego wyroku (triplex sententia conformis), nie była znana dekretalistom ${ }^{38}$, a została opracowana i utrwalona w sądownictwie kościelnym

tingit (Clem, 5, 11, 2) bliższe zasady procesu skróconego, a konstytucją Dispendiosam (Clem, 2, 1,2) zezwolił na to, by sprawy małzeńskie mogły być rozpatrywane drogą tego właśnie, skróconego procesu.

${ }_{37}$,Quavis. Includit spirituales, quasi spirituales, criminales, civiles et mixtas": Clem, 2, 11, 1, głosa ad v. Quavis.

${ }^{38}$,"There is some doubt in my mind whether at this time in the history of law three concurring sentences actually acquired the authority of 'res judicata'. Firstly because neither in Roman Law nor Decretal law was the term 'res judicata' expressly associated with these sentences - at best it might be inferred from the titles. Secondly, in Decretal law, a sentence after three concurring judgements and execution (Clem, 2, 2, 1) could have been attacked again which seemed to be against the very notion of 'res judicata'": Mangan M., Res judicata. An Historico Juridical Study, Rome 1962, 21, nota n. 39. 
poprzez jurysprudencję Roty Rzymskiej nie wcześniej, niż z początkiem XVI wieku ${ }^{39}$.

Uważam, że poglądu tego nie da się utrzymać w całej rozciągłości.

Prawdą jest, że samo ustawodawstwo kościelne zawarte w Corpus Iuris Canonici nigdzie bezpośrednio nie łączy trzech zgodnych wyroków z pojęciem res iudicata, prawdą jest również, że dopiero w XVI wieku spotykamy się z pewszechną opinią w nauce i jurysprudencji kościelnej, przypisującą trzem zgodnym wyrokom skutek, jakim jest przejście w stan rzeczy osądzonej.

Niemniej pierwsze przesłanki twierdzenia o przejściu wyroku w stan rzeczy osądzonej na skutek wyczerpania dopuszczalnych przez prawo dwóch apeiacji, spotykamy juz w połowie XIII wieku, a pierwszych jej Wyraźnych zwolenników pod koniec XIV wieku.

Jest rzeczą znamienną, że dekretaliści doszli do nowych wniosków w tym względzie wówczas, gdy starali się rozwiązac problem prawa procesowego wynikający z jednej strony z wyjęcia spraw duchowych od zasady przechodzenia wyroku w stan rzeczy osądzonej ${ }^{40}$, a $z$ drugiej stron y konieczności wykonania trzech zgodnych wyroków, także i w tych uprzywilejowanych procesowo sprawach

Już pep. Innocenty IV w swym komentarzy do Déretałów napisanym ok. r. $1251^{41}$ stwierdza, że jakkolwiek wyrok w sprawach małzeńskich nie przechodzi w stan rzeczy osądzorej ${ }^{42}$ i lrazda ze stron może przeciwko niemu wystapić, to jednak do ponownego rozpatrzenia sprawy wymagana jest słuszna przyczyna (,iusta causa"), a sędzia nie powinien latwo dopusaczać do nowego procesu. Autor daje przy tej okazji wyraz obawie, że gdyby nie stawiano ograniczeń w ponownym rozpatrywaniu wyroków nie przechodzących w stan rzeczy osacizonej, stworzyłoby to absurdainą sytuację, w kírej dopuszczalne byłyby trzecia, czwarta i dalsze apelacje ${ }^{43}$.

39 ,Alquanto più complesso invece si presenta il problema del passaggio in giudicato per l'esaurimento dei gradi del giudizio; comunque l'opinione prevalente al proposito propende per ritenere il passaggio in giudicato qualora su di una causa siano state pronunziate tre sentenze conformi... Così appaiono dalla giurisprudenza valorizzati agli effetti della formazione del giudicato, tanto il fatto dell'inerzia processuale, quanto la consunzione dei mezzi di gravame ordinari e straordinari": Musselli L., Il concetto di giudicato nelle fonti storiche del diritto canonico (Dalle origini al XVIIo secolo), Padova 1972, 126-127.

10 Zauważył to Della Rocca F., Il privilegio delle cause matrimoniali in ordine alla cosa giudicata nel diritto canonico, W: Saggi di diritto processuale canonico, Padova 1961, 3-4.

41 Van Hove A., Prolegomena, 477.

42 Innocentius IV, In quinque libros decretalium commentaria, Venetiis 1570 , Ad c. Lator: X, 2, 27, 7: ,Nota sententiam matrimonii non transire in rem iudicatam".

43 Tamże, ad. c. Tenor: X, 2, 27, 10: „Et si haec mulier non erat absens per contumaciam, iniusta est sententia. Si per contumaciam erat absens, sentencia est 
Dalszym krokiem w opracowaniu wzajemnych relacji między zakazem trzeciej apelacji w sprawach małżeńskich a zasadą, że wyroki w tych sprawach nigdy nie przechodzą w stan rzeczy osądzonej, było stanowisko zajęte przez glosę zwyczajną do Dekretałów pap. Grzegorza IX, opracowaną w 1263 r. przez Bernarda z Parmy ${ }^{44}$.

Glosa ta przyjmuje, że zakaz trzeciej apelacji ma zastosowanie także i do spraw mał̇̇eńskich ${ }^{45}$, ale $w$ stosunku do zasady przyjmującej, że sprawy małżeńskie nie przechodzą w stan rzeczy osądzonej, wprowadza rozróżnienie. Wskazuje mianowicie, że 'zasada ta nie posiada charakteru bezwzględnego i istnieje pewna kategoria wyroków w sprawach må̌żeńskich, które przechodzą w taki stan.

Glosa rozróżnia wyrok orzekający nieważność małżeństwa (,contra matrimonium”) od wyroku orzekającego jego ważność („pro matrimonio").

Bezwzględnie nigdy nie przechodzą w stan rzeczy osądzonej te sprawy mał̇eńskie, w których wyrok orzeka nieważność związku, oraz te, w których orzeka wprawảzie ważność małzenstwa, ale małżeństwo to jest i tak nieważne, bo zostało zawarte mimo istniejącej trwałej zrywającej przeszkody ${ }^{46}$.

Natomiast wyrok stwierdzający ważność małżeństwa, w którym nie było trwalej przeszkody, o ile od takiego wyroku nie apelowano, przechodzil w stan rzeczy osądzonej, strony bowiem przystaly na jego

Iusta ex ordine, sed quia potest iniusta esse causa, iterum auditur et sine appellatione, quod in causa matrimonii (est) speciale... Nec intelligas hoc ita generatiter verum, quod indifferenter sit admittenda contra sententiam matrimonii, nisí iusta causa moveat iudicem, quod ipsam audiat, sicut hic movit iudicem absentia mulieris. Sed si pars, contra quam lata fuit sententia praesens fuisset, non videtur quod fuisset admittenda contra sententiam, quia eadem ratione et tertio et quarto et in infinitum esset admittenda, quod satis esset absurdum... Credo tamen quod hane causae cognitionem (iudex) possit facere sine praesentia.partium et hoc ideo dico quia de iure est, quod uterque coniugum contra sententiam matrimonii audiatur, tamen iudex in hoc non debet esse facilis".

44 Bernard z Parmy, zwany też Bernardem z Botone napisał ostatnią redakcję glosy, przyjętej później za zwykłą, w 1263 r. tuż przed swoją śmiercią. Zob. Schulte F., Die Geschichte, t. II, 115; Van Hove A., Prolegomena, 473-474. Glosę Bernarda z Parmy cytuje za wydaniem: Decretales Gregorii papae IX suae integritati cum glossis restitutae, Venetiis 1584.

45 Glosa ad c. Fraternitatis: X, 4, 15, 6, ad v. Fornicario modo: ,... duae tantum sententiae post primam sunt ferendae, quia tertio appellare non licet".

46 ,Sententia lata contra matrimonium non transit in rem iudicatam, quin revocetur sententia quandocunque error sententiae detectus fuerit... Sic nullo tractu temporis matrimonium confirmatur in gradu prohibito contractum... Et quod dici consuevit, sententia contra matrimonium non transit in rem iudicatam verum est, ubi bene coniuncti indebite separantur, quia quos Deus coniunxit, homo separare non potest et ideo quandocunque contrarium legitime constiterit, sententia retractabitur. Idem est cum in grado prohibito aliqui sunt coniuncti vel ex aliquo alio perpetuo impedimento, quia nullum est ibi matrimonium, unde nullus consensus potest matrimonium inducere inter eos": X, 2, 27, 7, glosa ad v. Permanere. 
treść ${ }^{47}$. Podobnie, zdaniem Baldwina de Ubaldis ${ }^{48}$ przechodzi $\mathrm{w}$ stan rzeczy osądzonej wyrok $\mathrm{w}$ sprawie małżeńskiej $\mathrm{w}$ wypadku, gdy orzeka on ważność związku, który był wprawdzie nieważny $\mathrm{z}$ braku istotnego elementu jakim jest zgoda małżeńska, ale stał się związkiem ważnym na skutek wyrażenia zgody, albo na skutek dokonania faktów równorzędnych z taką zgodą (np. wspólne zamieszkanie, współżycie fizyczne małżonków itp.), o ile tylko w momencie powstawania związku nie było między kontrahentami przeszkody zrywającej ${ }^{49}$.

Wypracowane przez glosę do Dekretałów Grzegorza IX rozróżnienie wyroków pro matrimonio i contra matrimonium, oraz przypisanie, wyrokom pro matrimonio możliwości przejścia w stan rzeczy osądzonej mimo zasady, że sprawy małżeńskie mogą być zawsze na nowo rozpatrywane, pozwala nam nie widzieć sprzeczności między panującą w nauce opinią a wypowiedziami niektórych autorów.

Tak więc Antoni a Butrio ${ }^{50}$ komentując znane c. Lator stwierdza, że wyrok w sprawie małżeńskiej przechodzi w stan rzeczy osądzonej tak, że nie można go ponownie rozpatrywać, jeżeli został potwierdzony dwukrotnie 51. Antoni a Butrio jest zatem pierwszym autorem, który przypisuje trzem zgodnym wyrokom ${ }^{52}$ skutek $\mathrm{w}$ postaci przejścia $\mathrm{w}$ stan rzeczy osądzonej.

Podobne, chociaż mniej pewne stanowisko $\mathrm{w}$ sprawie res iudicata, która powstaje na skutek trzech zgodnych wyroków, zajmuje Jan z Imo-

47 Tamże: „Sed ubi sententia fertur pro matrimonio, ubi nullum subest impedimentum, si ab ea non fuerit appellatum, transit in rem iudicatam, quia iudicatis acquievisse videtur ... unde postea non audietur, imo compelletur alter alteri adhaerere". Nieścisłe jest zatem twierdzenie zawarte w artykulle Arregui A., Sobre la cosa juzgada en las causas matrimoniales, Jus Canonicum, IV (1964) 570, który mówiąc o przywieleju wyjęcia spraw małżeńskich „,pro vinculo” od zasady przejścia wyroku w stan rzeczy osądzonej, dodaje, że glosatorzy ,extienden el privilegio a los casos contra matrimonium".

18 Legista, ale komentujący również dekretały. Zmarł w 1400 r. Zob. Schulte F., Die Geschichte, t. II, 275-277; Van Hove A., Prolegomena, 496.

49 „Quero quid utrum erronea sententia lata pro matrimonio transeat in iudicatum, responditur si aliquis consensus potest reconciliari matrimonium transit. Secus si consensus est omnino prohibitus non transitus potest fieri de non esse ad esse, sed de non esse ad non essse non est transitus": Baldus de Ubaldis, Commentarius super libro I, II, III decretalium, Lugduni 1525, X, 2, 27, 7.

50 Profesor w Bolonii, Perugii, Florencji i Ferrarze. Przedstawiciel ówczesnego laikatu wśród kanonistów. Zmarł w 1408 r. Zob. Schulte F., Die Geschichte, t. II, 289-294; Van Hove A., Prolegomena, 496-497.

51 ,Item transit in rem iudicatam si secundo est confirmata sententia in causa matrimoniali, ut postea non possit retractari": Antonius a Butrio, In secundam secundi decretalium partem commentaria, $\mathrm{X}, 2,27,7, \mathrm{n} .8$.

52 U tegoż autora można również spotkać ciekawy termin ,plures sententiae consonantes", będący poprzednikiem rozpowszechnionego nieco później określenia ,sententiae conformes". Antoni z Butrio pisze w komentarzu do X, 2, 27, 17: "Nota secundo, quod in eadem causa et diversa instantia valent plures sententiae consonantes. Hodie victus, contra quem latae sunt tres sententiae, non auditur de nullitate, nisi plene sit s cta earum executio". 
li 53 twierdząc, że wyrok w sprawach małżeńskich przechodzi w stan rzeczy osądzonej w tym znaczeniu, że jeśli nie złożono w stosunku do niego apelacji, domniemywa się, że został wydany słusznie, chyba że twierdzenie przeciwne zostanie udowodnione. Opowiada się on także za tezą, że trzy zgodne wyroki, nawet w sprawach małżeńskich, przechodzą w stan rzeczy osądzonej, sekundując w tym Antoniemu a Butrio ${ }^{54}$.

W drugiej połowie XIV i w XV w. świadectw takiego stanowiska kanonistów jest już wiele, chociaż nie wszyscy wypowiadają się wystarczająco jasno. Niejasności te dotyczą nie tylko opinii, że trzy zgodne wyroki powodują powstanie res iudicata, ale także zrozumienia tejże res iudicata w sprawach małżeńskich.

Niektóre teksty zdają się mówić o przejściu wyroku w sprawach małżeńskich w stan rzeczy osądzonej tylko wówczas, gdy wyrok jest pro matrimonio, domagając się do ponownego rozpatrzenia sprawy po trzech zgodnych wyrokach, stwierdzenia oczywistej i notorycznej przeszkody małżeńskiej, przez co dają do zrozumienia, że brak takiej przeszkody nie pozwala wznowić sprawy, która przeszła w stan rzeczy osądzonej.

Przykładem takiej możliwości rozumienia tekstu może być cytowany już Antoni a Butrio czy Gwi don $\mathrm{P}$ a pa ${ }^{55}$.

Inne natomiast teksty zdają się przyjmować, że wyrok w sprawach małżéskich wprawdzie nigdy nie przechodzi w stan rzeczy osądzonej i może być pod określonymi warunkami zmieniony, niemniej bądź ze względu na zaniechanie apelacji, bądź z tej racji, że wyczerpano w sprawie dopuszczalną ich liczbę, uzyskuje specyficzny stan czy stopień trwałości.

W przeciwieństwie do spraw, w których wyroki osiągają poprzez przejście w stan rzeczy osądzonej bezwzględną trwałość, wyroki w spra-

53 Ur. m. r. 1367-1372, zmarł w 1436 r. Zob. Schulte F., Die Geschichte, t. II, 296-298; Van Hove A., Prolegomena, 497.

54 ,Transit in rem iudicatam quo ad hoc ut si non appelletur pro ea praesumitur donec aliud appareat... Item videtur transire in rem iudicatam, si sententia primo lata sit postea bis confirmata": Joannes de Imola, Lectura in I et II decretalium, Lugduni $1547, \mathrm{X}, 2,27,7$, n. 5-6. Podobnie $\mathrm{w}$ innym tekście: ,... potest quis illud (sc. negotium) prosequi appellando a diffinitiva, non poterit tamen quando transivit in rem iudicatam ex bina appellatione repulsa": Joannes de Imola, Commentarius. in titulum de appellationibus, Spirae 1598, 113. Także w komentarzu do Klementyn: „Nota primo quod licet remedia rescindendi sententiam ex appellatione non competant ultra bis... tamen ius discendi de nullitate competit ultra ter... Nota quarto, quod exceptio nullitatis sententie impedit executionem sententie nisi ubi plures vel saltem tres sententie sint late consonantes": Joannes de Imola, Opus in Clementinas, Venetiis 1492 (inc.), Clem, 2, 11, 1.

55 Zmarł w 1487 r. Zob. Van Hove., Prolegomena, 500-501. Pisze on: „Item etiam transit in rem iudicatam sententia lata in causa matrimoniali quo ad hoc, ut si non appelletur preasumatur pro ea, donec contrarium appareat... Item et quarto transit in rem iudicatam si sententia lata in causa matrimoniali bis fuerit confirmata, quia postea retractari non poterit, nisi appareret evidens et notorium impedimentum": Guido Papa, Super decretales commentaria, Lugduni 1528, X, 2, 27, 7, n. 2. 
wach małżeńskich ${ }^{56}$, poza wyliczoną już kategorią wyroków pro matrimonio, mogą osiągać jedynie trwałość względną. Wprawdzie dekretaliści także i w stosunku do wyroków w sprawach małżeńskich mówią „transeunt in rem iudicatam”, dodają jednakże bliższe określenie np. „quoad instantiam causae”, ,ut postea non possit retractari”, „quo ad hoc ut si non appelletur pro ea praesumitur donec aliud appareat". - Tego typu pogląd będzie reprezentowało wielu kanonistów XV wieku, ale najpełniejsze opracowanie znajdzie on u sławnego Mikołaja de Tudeschis, zwanego Abbas Panormitanus ${ }^{57}$.

Zastanawia fakt, że Panormitanus widzi jako przyczynę przejścia wyroku w stan rzeczy osądzonej wyłącznie upływ dziesięciodniowego terminu wyznaczonego na apelację, nigdzie natomiast nie mówi, by taką przyczyną było wydanie $w$ sprawie trzech zgodnych wyroków. Fakt ten świadczy niewątpliwie o tym, że pogląd reprezentowany przez Antoniego a Butrio i kilku innych dekretalistów, nie był jedynym i powszechnie przyjętym.

Panoramitanus uważa, że sprawy małżeńskie nigdy nie przechodzą w stan rzeczy osądzonej, z wyjątkiem wskazanej już wyżej kategorii wyroków pro matrimonio ${ }^{58}$, ale też nie mogą być rozpatrywane w nieskończoność. Zakaz trzeciej apelacji ma do nich zastosowanie na równi $\mathrm{z}$ innymi sprawami. Po upływie dziesięciu dni po wyroku, jeżeli apelacja nie zostanie wniesiona, lub po dziesięciu dniach od trzeciego zgodnego wyroku, kiedy już więcej apelować nie wolno, wyrok osiąga pewną trwałość. Panoramitanus określa tę trwałość mówiąc: „transit in rem iudicatam quoad praesumptionem iustitiae".

Ponowne rozpatrzenie sprawy jest wprawdzie możliwe, ale tylko wówczas, gdy strona podważająca jego ważność udowodni błąd, na którym został oparty wyrok. Ponieważ po upływie dziesięciu dni od wyroku przechodzi on w stan rzeczy osądzonej "quoad instantiam causae", do ponownego rozpatrzenia sprawy wymagana jest nowa skarga i nowy proces ${ }^{59}$.

56 O wyrokach ,W sprawach małżeńskich" mówię tu dlatego, że ten problem interesuje mnie przede wszystkim. $\mathrm{Na}$ ogół dotyczy on jednak szerszej problematyki wyroków w sprawach duchowych.

${ }_{57}$ Ur. w 1386 r. w Katanii, był profesorem w Bolonii, Parmie i Sienie. Zmarł jako opat benedyktyński w Palermo w 1445 lub 1453 r. Zob. Van Hove A., Prolegomena, 497.

${ }_{58}$,Unde, si sententia est lata contra legitimum matrimonium, vel pro matrimonio, quod quidem obstante canonico impedimento subsistere non potest, nunquam transit in rem iudicatam..., secus si fuit lata pro matrimonio nullo subsistente impedimento, quia tunc ex eius observantia non nutritur peccatum, ut praedixi, debent ergo partes de novo consentire": Nicolaus de Tudeschis, Commentaria tertiae partis in secundum librum decretalium, X, 2, 27, 7, n. 9.

59 ,Sententia contra matrimonium non transit in rem iudicatam, unde quandocunque revocatur cum constat de errore... tamen antequam de errore doceatur, pro ea et eius iustitia et processu praesumitur et est observanda, donec constiterit eam 
Panormitanus, który przekazał nam niemal cały dorobek kanonistyki ,złotego wieku" na temat interesujących nas instytucji prawa procesowego, stał się autorytetem w tej dziedzinie na wiele wieków.

Zarówno uczeni kanoniści jak i prawnicy praktycy XVI-XVII wieku będą często do niego odsyłali swoich czytelników.

Nauka Panormitana w zakresie trzeciej apelacji posiada jednak jedną lukę, na wypełnienie której chyba świadomie autor się nie zdecydowal, trudno bowiem przypuścić, by nie zauważył on rozwiązań proponowanych przez wcześniejszych od siebie kanonistów. Chodzi o to, że Panormitanus nigdzie $w$ swoich dziełach nie uznał, by skutkiem trzech zgodnych wyroków było ich przejście w stan rzeczy osądzonej.

Fakt ten dziwi przede wszystkim dlatego, że wielu autorów piszących po Mikołaju de Tudeschis i powtarzając za nim niemal dosłownie szerokie wywody na temat zakazu trzeciej apelacji i skutków trzech zgodnych wyroków, bez wahania przyjmują tezę Antoniego a Butrio i Jana z Imoli, tak że w XVI wieku jej przyjęcie można uznać za powszechne.

Spośród wielu autorów opowiadających się za twierdzeniem, że trzy zgodne wyroki przechodzą $w$ stan rzeczy osądzonej, wystarczy wymienić takich jak Aleksander de Nevo ${ }^{60}$, czy Dydak Covarruvias ${ }^{61}$, a zwła-

iniustam fuisse, unde afferenti fraudem seu errorem incumbit onus probandi... In istis sententiis, quae non transeunt in rem iudicatam, potest probari iniustitia tam respectu meritorum causae quam respectu ordinis processus per acta causae, licet transiverit decendium a tempore sententiae... Et circa huiusmodi sententias, quae non transeunt in rem iudicatam, cape aliquas limitationes notabiles. Primo enim scias, quod post decendium non potest appellari... Secundo non potest in talibus causis appellari tertio, sicut nec in aliis causis... Licet sententia in causa matrimoniali non transeat in rem iudicatam, non tamen debet post decem dies quis indifferenter admitti ad probandum contrarium, sed oportet quod allegetur aliqua iusta et verisimilis causa iniustitiae quae habeat movere iudicem ad credendum illam iniustam. Unde non debet esse iudex facilis in audiendo partem contra illam. Nam si diceremus contrarium, sequeretur... quod eadem ratione et tertio et quarto et in infinitum esset pars contraveniens admittenda, quod videtur absurdum. Ex hoc ego noto, quod non potest dari certa regula, quotiens debeat pars admitti contra sententiam, sed iudex aestimabit an et quando ex causa, quae coram eo allegatur... Quarto dico, quod sententia transit in rem iudicatam post decendium quoad instantiam causae et est opus novo iudicio": Nicolaus de Tudeschis, Commentaria tertiae partis in secundum librum decretalium, X, 2, 27, 7, n. 1-12.

60 ,Licet sententia in causa matrimoniali non transeat in rem iudicatam, quominus "possit detecto errore revocari, tamen antequam de errore doceatur est observanda, donec constiterit eam fuisse iniustam et afferenti fraudem vel errorem incumbit onus probandi. Ex quo infertur, quod praesumitur pro sententia, quae non transivit in rem iudicatam et pro eius iustitia et pro processu... Si talis sententia sit confirmata per duas alias sententias, transit in rem iudicatam quo ad matrimonium ... talis sententia transit in rem iudicatam quo ad iustitiam causae unde es opus novo processu vel quod pars admittatur per viam restitutionis in integrum": Alexander de Nevo, In secundum decretalium librum commentaria, Venetiis 1583, $\mathrm{X}, 2,27,7$, n. 3 i 11 .

${ }_{61}$, Ex eo... quod terminus legalis labitur omnino, nec a sententia provocatur, vel $a b$ ea bis fuerit provocatum, ita assumit sententia authoritatem rei iudicatae, etiam in coniugali quaestione, ut praetextu appellationis corrigi, aut emendari nequeat... Ex quibus constat primo eum qui hanc sententiam improbare vellit, debere omnino probare eius errorem et iniquitatem; siquidem non proposita appellatione est maxima praesumptio pro iustitia sententiae, glossa communiter approbata 
szcza piszącego na ten temat wyjątkowo jasno Tomasza Sanches $(\dagger 1610)$ w znanym dziele De sancto matrimonii sacramento opublikowanym po raz pierwszy w Genui w 1602 r. Autor ten zajmuje się specjalnie problematyką związaną ze skutkami potrójnego zgodnego wyroku w sprawach małżeńskich.

Potwierdza on w całej rozciągłości zasadę, według której wyroki w s’rawach małżeńskich nigdy nie przechodzą w stan rzeczy osądzonej, na skutek czego można je na nowo rozpatrzeć, ilekroć stwierdzi się, że poprzedni wyrok został oparty na błędnych podstawach ${ }^{62}$. Jednakże zaniechanie apelacji lub potwierdzenie pierwszego wyroku przez dwa następne powoduje ten skutek, że nie można się już więcej posłużyć apelacją, pozostaje natomiast do dyspozycji jedynie skarga o nieważność wyroku ${ }^{63}$.

Ponadto pewien stopień trwałości wyroku w sprawach małżeńskich, który Sanches, podobnie jak Panormitanus określa terminem ,transitus in rem iudicatam" ujawnia się w tym, że może zwalczać taki wyrok tylko ten, kto jest w stanie przytoczyć prawdopodobną przyczynę jego niesłuszności ${ }^{64}$, jeżeli posłuży się nową skargą powodową ${ }^{65}$, wreszcie trwałość ta objawia się poprzez fakt, że wyrok taki przechodzi w stan rzeczy osądzonej w stosunku do orzeczonych w nim wydatków sądowych ${ }^{66}$ oraz w odniesieniu do osób trzecich ${ }^{67}$.

Do dyskusji nad zakazem trzeciej apelacji dorzucili pewien nowy element także kanoniści XVII wieku, rozważając problem, czy wyrok wydany przez sędziego, do którego wniesiono sprawę przy pomocy trze-

in d. c. Lator ... Secundo huic constat, ad hoc ut ista sententia rescindatur oportet, ut condemnatus nova utatur querela, novoque libello, quo petat id negocium praetextu sententiae erroneae iam diffinitum, iterum ad examen iudiciale deduci, primamque sententiam revocari, ac novam, iustitia exigente proferri": Covarruvias Didacus, In quartum librum decretalium epitome, Lugduni 1558, pars 2, cap. 8, n. 12 .

62 ,Praemittendum est, id matrimonii speciale esse, ut sententia in coniugali causa lata, quacumque circumspectione praemissa, sive bis ad ea provocatum fuerit, confirmataque sit, sive lapsus terminus ad appellandum sit, nunquam transeat in rem judicatam, ac proinde non ita efficacem auctoritatem sortiatur, quin retractanda sit, quoties compertum fuerit, eam errore quodam latam fuisse": Sanches Thomas, De sancto matrimonii sacramento, t. II, Venetiis 1737 , lib. 7 , disp. 100, n. 1.

${ }_{63}$ Tamże, n. 4: „Intellige tamen primo non transire in rem judicatam sententiam matrimonii, a qua decennio appellatum non est, vel duplici sententia confirmatam, ad hunc sensum, quin per viam querelae possit contra eam allegari. At sumit auctoritatem rei judicatae, ut praetextu appellationis corrigi nequeat".

64 Tamże, n. 5: „Secundo intellige, quamvis non omnio transeat in rem judicatam (sc. sententia in causa matrimoniali) transire tamen quo ad hoc, ut non indiscriminatim eam impugnare volens audiatur, sed oportet alligare aliquam verisimilem iniustitiae causam, quae iure optimo iudicem ad id credendum ducat, ne in infinitum pars contraveniens audiatur".

${ }_{65}$ Tamże, $\mathrm{n}$.8: „Ut haec sententia rescindatur oportet condemnatum uti nova querela, novoque libello... nam quoad instantiam causae transit in rem judicatam".

66 Tamże, n. 11: „Intellige sententiam matrimonii non transire in rem judicatam, quoad ipsum coniugium, secus quoad expensas quarum succumbens condemnatus fuit per eam sententiam, a qua non est appellatum".

${ }_{67}$ Tamże, n. 12: „Quarto intellige non transire in rem judicatam respectu coniugum, at transire respectu tertii contra matrimonium agentis". 
ciej zakazanej apelacji, jest ważny czy nie. Argument za ewentualną ważnością takiego wyroku czerpano stąd, że prawo nie zabraniało wprost wydania w takiej sytuacji wyroku a tylko nie zezwalało na trzecią apelację, zatem, jeżeli strona zainteresowana nie złożyła sprzeciwu, jurysdykcja sędziego ulegała przedłużeniu i wyrok był ważny. Opinię tę, reprezentowaną przez XIV-wiecznego legistę Baldwina de Ubaldis $(\dagger$ 1400) i kanonistę z XVI w. Filipa Deciusa ( $\dagger$ 1537) zwalcza Emanuel Gonzales Tellez ( $†$ 1649) broniąc w ten sposób ostatnich już w kanonistyce ataków na skuteczność zakazu trzeciej apelacji. Jego zdaniem wyrok wydany na skutek trzeciej, zabronionej apelacji, jest nieważny dlatego, że sędzia nie posiada do rozstrzygnięcia sprawy żadnej jurysdykcji, bo zakazana apelacja nie powoduje żadnych skutków ani zawieszających, ani odwlekających w stosunku do poprzednich wyroków ${ }^{68}$.

W pierwszej połowie XVIII wieku doktryna w zakresie trzeciej apelacji była powszechnie przyjęta. Uważano, że odnosi się ona do wszystkich spraw, także i duchowych, a wyczerpanie dozwolonych apelacji powoduje przejście wyroku w stan rzeczy osądzonych, przy czym stan ten dla spraw małżeńskich nie wykluczał możliwości wznowienia sprawy, ale już nie drogą apelacji.

Poglądy takich autorów tego okresu jak Jana Baptysty De Luca ${ }^{69}$, Henryka Pirhinga 70, Anakleta Reiffenstuela 71, Zegari Bernarda Van Espen ${ }^{72}$ czy Franciszka Schmalzgruebera ${ }^{73}$ są na ten temat co do istoty jednakowe.

68 ,Utrum valida sit sententia lata a judice, ad quem tertio provocatum est? Et pro negativa sententia facit, quod tertia appellatio simpliciter et absolute prohibetur, unde neque suspensivum, nec devolutivum effectum producere valet, ac proinde circa illam causam nulla in judicem ad quem transfusa est jurisdictio et per consequens sententia $a b$ eodem, tanquam a non suo judice lata, valere non potest... Fecit etiam, quia si sententia valeat, offenduntur omnia, quae pro ratione huius decisionis adduxi; offenditur namque praesumptio, quae est pro judice, quod toties a vero tramite non deviavit, lites non finiuntur, ac tandem appellatio fit praesidium iniquitatis". Wprawdzie Baldwin de Ubaldis i Decius są innego zdania, ale „,cum nullam huius discriminis rationem expendant, neque pro singulis membris aliquod fundamentum afferant, audiendi non sunt. Dicendum ergo est, sententiam prolatam a judice, ad quem tertio provocatum fuit, nullam esse, non propter directam legis resistentiam, sed ex alio capite, quia videlicet prolata est a non suo judice, unde ex defectu substantiali, jurisdictionis videlicet, sententia nulla est, nec credi potest partem injuste provocatam consensisse, aut prorogasse": Gonzalez Telez Emanuel, Commentaria perpetua in singulos textus quinque librorum decretalium Gregorii IX, Maceratae 1733, t. II, X, 2, 27, 65, n. 8.

69 De Luca Joannes Baptista, Theatrum veritatis et iustitiae, t. XV De iudiciis et iudicialibus, Lugduni 1697 , disc. 37 , n. 8.

70 Pirhing $H$., Ius canonicum nova methodo explicatum, t. II, Dilingae 1675, lib. 2 , tit. 27 , sect. 4 , n. $114-116$.

71 Reiffenstuel Analectus, Ius canonicum universum, t. II, Romae 1832, lib. 2, tit. $27, \S 11$, n. $312-315$.

72 Van Espen Z., Ius canonicum universum, t. II, pars 3, tit. 10, cap. 1, n. 2937 , s. $359-360$.

${ }_{73}$ Schmalzgrueber F., Ius ecclesiasticum universum, ‘. II, Romae 1844, pars 3, tit. $27, \S 3$, n. 64,2 ; tit. $28, \S 5$, n. 67 . 
Nowe, poważne zmiany $\mathrm{w}$ tej dziedzinie dokonywały się już od dawna $w$ ustawodawstwach cywilnych, poprzez wprowadzenie $w$ miejsce zasady potrójnego zgodnego wyroku, czy zakazu trzeciej apelacji, znacznie surowszej zasady podwójnego zgodnego wyroku i zakazu drugiej apelacji.

. Duży wpływ na przejęcie tej surowszej zasady do prawa kanonicznego miało ius commune, a główna rola w przyswojeniu tych nowych instytucji prawnych kanonistyce przypadła w udziale papieżowi Benedyktowi XIV.

\section{TRIPLEX SENTENTIA CONFORMIS NEL DIRITTO DELLE DECRETALI}

\section{S O M M A R I O}

Il divieto del terzo appello, desunto da G ra zi a no dal diritto romano, ha dato origine alla dottrina sulla triplice sentenza conforme, elaborata fondamentalmente dai decretisti e sviluppata poi dai decretalisti.

Secondo i decretisti tre sentenze conformi non permettevano il terzo appello e la causa davanti al giudice ecclesiastico era finita. Soltanto nelle cause spirituali e specialmente in quelle matrimoniali, per ragioni etiche, si poteva appellare fin quando la verità obiettiva non venisse scoperta.

Questa dottrina dei decretisti sulla triplice sentenza conforme ha ottenuto la conferma da parte della legislazione ecclesiastica nei decretali di papa Gregori o IX (cf. c. Directae - X, 2, 28, 39 di papa Cle mente III (1187-1191) e il c. Sua nobis - X, 2, 28, 65 di papa O nor i o III (1216-1227)).

Nonostante nei decretali la prassi dei giudici ecclesiastici non era uniforme e permetteva - secondo come scrive G. Durante nel suo famoso Speculum iuris -la situazione nella quale era lecito appellare ben cinque volte e le cause nei tribunali non finivano mai.

L'autore sostiene che Antonio da Butrio e Giovanni da Imola furono fra i primi decretalisti che hanno collegato strettamente il divieto del terzo appello, cioè il principio della terza sentenza conforme con la res iudicata. In consequenza dopo la terza sentenza conforme non era più permesso appellare perchè esisteva già la cosa giudicata.

Le cause spirituali, e specialmente quelle matrimoniali, dopo le tre sentenze conformi potevano essere esaminate di nuovo, ma solo quando la sentenza contenesse errori, però non tramite l'appello ma usando altri mezzi per riformare la sentenza.

Secondo l'autore con la prima metà del sec. XVIII la dottrina sulla terza sentenza conforme e sulla sua efficacia, cioè sulla cosa giudicata da essa provocata, può essere considerata come comunemente accettata. 